\title{
Learning Media Based on Techno Pedagogical Content Knowledge
}

\author{
Marice $^{1}$, Isda Pramuniati ${ }^{2}$, Jubliana Sitompul ${ }^{3}$ \\ \{mega_pangrib@yahoo.co.id \} \\ Faculty of Language and Arts, Universitas Negeri Medan, Indonesia ${ }^{1,2,3}$
}

\begin{abstract}
The learning process without media will make students' learning outcomes tend to be low, because learning is monotonous and boring. It will be different, if learning is supported by technology-based learning media. Students will be passionate about learning and motivated to learn. Therefore, the development of TPACK-based learning media for this reading course will greatly assist lecturers in delivering learning material, in addition to motivating students to learn. This research \& development research aims to find out how the development process of learning media in French Reading Courses is equivalent to A2 based on techno pedagogy content knowledge (TPACK) and how the quality of learning media developed is based on the results of content and construct validation tests. The development of learning media for reading courses needed to be conducted, given that current learning must be in contact with digitalization or Web-based. This research was conducted at the French Department of Language and Arts Unimed. Plomp's development model (1997: 6-15) was conducted as a methodology consisting of four stages, namely (1) the investigation phase, (2) the design phase, (3) the phase of realization or construction, (4) the test, evaluation and revision phases. Information gathering was associated with the importance of developing learning media for reading French as equivalent to A2. The stage also simultaneously carries out mapping of learning and material objectives, while data collection is the collection of materials or materials that are included in the learning media that are developed using the Edmodo application, namely the network used by teachers for various content, distributing quizzes, assignments, and managing communication with learners. At the planning stage it was mapped or compiled material that was appropriate to the learning objectives, as well as the preparation of the right design. At the development stage, the material preparation activities were carried out into the planned design. After reading learning media was developed, expert validation was carried out, namely by native speakers and design experts and instructional media experts. Based on expert opinion, revision or improvement of understanding reading text in French text based on TPACK was made. This paper presented that the results of data collection, namely the mapping of learning objectives, indicators, materials and technology that were used as a forum that was suitable for the learning objectives and students character.
\end{abstract}

Keywords: Teaching media, reading, TPACK

\section{Introduction}

Learning Media in learning French is needed to support the achievement of students' competence in mastering four language skills. French as one of the foreign languages taught at Medan State University requires having French language competence at level B1 after 
graduation. Therefore, it is very important to provide good facilities, one of which is learning media. Based on the results of the interview the author explores the needs of the French Language Education Study Program. The media used during learning does not yet exist, specifically for reading skills. The learning process still tends to lecture using Power Point media or watching videos, and listening to audio. Interviews conducted to students also produce conclusions, that the learning process is still monotonous because it only deals with text, then other questions and exercises related to the text.

In order to expand exploration, the author sees the results of student scores on reading skills. The competence of the second semester students was apparently still low on average, especially on reading skills. If asked to answer questions about the text, the answer that can be given is if the answer is in the text. If the question is outside the text, but related to the text the student will difficult to answer. Students' insights about the themes given are still lacking. The following are student learning outcomes on reading skills.

Table 1. Student Competencies in Reading Skill

\begin{tabular}{lllll}
\hline Students & $\begin{array}{l}\text { UTS } \\
\text { Score }\end{array}$ & $\begin{array}{l}\text { Number of } \\
\text { Students } \\
(\%)\end{array}$ & $\begin{array}{l}\text { UAS } \\
\text { Score }\end{array}$ & $\begin{array}{l}\text { Number of } \\
\text { Students } \\
(\%)\end{array}$ \\
\hline $2^{\text {nd }}$ Semester & $80-100$ & 20 & $80-100$ & 20 \\
& $70-79$ & 40 & $70-79$ & 40 \\
& $60-69$ & 30 & $60-69$ & 30 \\
& $\ldots-59$ & 10 & $10-59$ & 10 \\
\hline
\end{tabular}

Based on the data and the results of exploration need above, nowadays the author developed technology-based learning media. In addition, the KKNI curriculum is now being used at the State University of Medan, requiring the use of technology in accordance with the concepts and principles of learning. Techno-Pedagogical Content Knowledge abbreviated TPACK) is a demand for every learning. Therefore, through the development of reading learning media, it is expected that competence in reading skills can improve.

The author teaches reading courses for level A2. This course teaches students to be able to understand French text equivalent to A2 and be able to discuss the text according to the theme. Thus, the authors develop learning media in reading courses. Learning media has an important role in every learning. Usman (2001) stated that learning media provides many benefits for students, namely to put concrete foundations into thinking, increase attention, make learning more permanent or not easily forgotten, provide real experiences so as to foster independent learning, regular and continuous thinking, and help growing understanding and fostering language skills.

Especially for reading skills, learning media is very rarely found that can be a supplement to these skills. French learning media for other skills, such as speaking skills, listening skills, grammar, spelling, writing sentences, very much. However, for reading skills, understanding text is very rare. This strengthens the author to develop a "reading" learning media based on Techno-Pedagogical Content Knowledge. 
It is not easy to enter long texts into an application so that they can be used as media. Therefore, the authors develop variations in the material on learning media. That is, in order to understand the text, students are assisted by presenting pictures, videos, or short sentences, to direct students' understanding. While the text will be presented per paragraph or by using hyperlink.

\section{Literature Review}

Learning media development is the process of describing learning objectives and learning material in a concise way by creatively becoming a single entity in one container. The container contains learning materials that are learning resources that are very useful for learners. Learning media is part of teaching material, which is useful as a support for learning material. Tomlinson (1998: 9) states that the development of teaching materials is everything that is used in learning, in the form of textbooks, text books, exercise books, cassettes, CD Roms, videos, handouts, etc., which of course contain information about the content of learning. In connection with the development of teaching materials, Tomlinson also argued that the development of teaching materials is everything that is done by authors, teachers and even students to provide input sources for learning that contain information about the content of learning. Based on Tomlison's explanation, it can be concluded that the development of learning media as part of the development of teaching materials

Compréhension écrite A2 : "Je peux lire des textes courts très simples. Je peux trouver une information particulièrement prévisible dans des documents courants comme les petits publicités, les prospectus, les menus et les horaires et je peux comprendre des lettres personnelles courtes et simples" (CECRL)

Lire, c'est traiter un ensemble d'informations écrites(http://www.cndp.fr/crdpdijon/librairie/bonnes_feuilles/210b5370-qu-est-ce-quelire.pdf)

Savoir lire, c'est être capable d'oraliser avec précision, flui-dité, en respectant la segmentation et en mettant l'emphase sur certains éléments (prosodie), en retenant des informations littérales et en faisant des inférences découlant des informations littérales. Lire, c'est réagir au texte ; lire, c'est raisonner.

The reading termis referred to as a process of combining information from a text and background of students' knowledge in order to build meaning. In building this meaning, students need reading skills that is a skill possessed by students in themselves so that they are able to apply it in an action as an implementation of the language's knowledge and cognitive abilities. According to Tagliante (1994: 35), l'apprentissage est un processus actif, ... "qui se déroule à l'intérieur de l'individu et qui est susceptible d'être avant tout influencé par cet individu. It means that learning is an active process, which takes place from within the individual and is likely to be influenced by the individual himself. Reading skills are one of the language skills needed to understand a text. Desmons (2005: 49) stated that understanding a foreign language text not only requires the reader to have linguistic competence but also cultural competence. Reading is often said to be passive language skills. Nunan (1999: 199) said that in the acquisition of second language, many people think that reading and listening are the second skill after speaking and writing. 


\section{Research Methods}

This research is a qualitative descriptive study. In order to collect the desired data, the technique used is documentation technique that is the collection of documents related to important data for the development of reading teaching materials. Document analysis is useful to complement and clarify the results of information, namely by observing, recording and collecting what is implied and written in each document or archive that is the source of the data. Documents can take the form of writing, such as diaries, life histories, stories, biographies, regulations and policies. Documentation in the form of images, such as photos, live images, sketches and others. Documents in the form of monumental works from someone such as artwork, which can be in the form of pictures, sculptures, films, etc.

In the data presentation section, data distribution techniques are used in TPaCK. In accordance with the TpaCK image as follows.

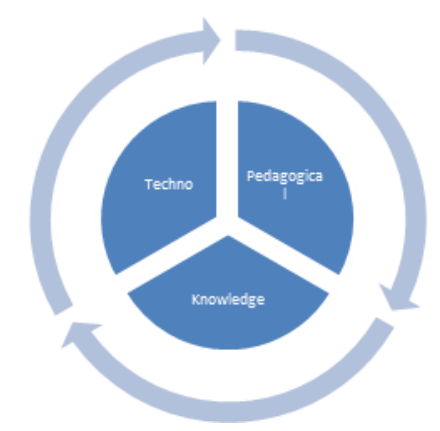

Figure 1. TpaCK Cycle in the Teaching Materials Development

According to the picture, the data collected will be sorted into the content of the technology used, draw pedagogical lines and knowledge about pedagogical content and content of technology and information from the text. Data collected according to documentation analysis is then mapped in a table.

\section{Discussions}

In accordance with the purpose of the research, namely the development of TPACK learning media, what will be produced is a media. However, as the basic material of the media is data related to reading skills that will be supported by the media. The discussion of this paper contains the results of data collection and then mapped in the table. The preliminary data presented are related to KD-GPA and Material as follows. 
Table 2. Mapping of KD, GPA, Material A2

\begin{tabular}{|c|c|c|}
\hline $\begin{array}{l}\text { Basic } \\
\text { Competencies }\end{array}$ & Indicator & Materials \\
\hline $\begin{array}{l}\text { Able to } \\
\text { understand } \\
\text { simple texts } \\
\text { related to one's } \\
\text { self description }\end{array}$ & $\begin{array}{l}\text { Understanding the } \\
\text { dialogue text related to } \\
\text { self-introduction } \\
\text { Understanding the } \\
\text { dialogue texts related to } \\
\text { introducing others } \\
\text { Answering questions } \\
\text { related to self- } \\
\text { introduction dialogue } \\
\text { Answering related } \\
\text { questions introducing } \\
\text { others } \\
\text { Able to introduce yourself } \\
\text { with A2 level level } \\
\text { language } \\
\text { Able to introduce others } \\
\text { to A2 level languages } \\
\text { Retelling the identity of } \\
\text { others verbally with A2 } \\
\text { level language } \\
\text { Rewrite the other people's } \\
\text { identities in text form } \\
\text { with A2 level language } \\
\text { Rewrite the other people's } \\
\text { identities in biographical } \\
\text { form with A2 level } \\
\text { language }\end{array}$ & $\begin{array}{l}\text { 1. Self Introducing Text } \\
\text { Dialogue } \\
\text { 2. Teks Dialog Introducing } \\
\text { others Text Dialogue }\end{array}$ \\
\hline
\end{tabular}

The materials in the table above are the first presentation on the initial learning in chapter one. The data needed from the table for the Techno element are Indicators and Materials, for Pedagogical elements are Indicators and Test Items to be developed, while Knowledge is the students' knowledge of the relationship between KD-GPA-Material and Test Items as well as the knowledge conveyed through the text.

The following is an explanation between the Indicator with the Material or Test Items and Techno. These elements will be described in a table, but in the development of materials, the table is the basis for developing the technology.

Table 3. Linkages between GPA-Pedagogic-Technology

\begin{tabular}{lll}
\hline Indicator & Pedagogical & Technology \\
\hline $\begin{array}{l}\text { Understanding the dialogue } \\
\text { text related to self- }\end{array}$ & Self & \\
introduction & $\begin{array}{l}\text { Introduction } \\
\text { Dialogue }\end{array}$ & Windows Movie Maker \\
$\begin{array}{l}\text { Understanding the dialogue } \\
\text { texts related to introducing }\end{array}$ & Introduction & \\
\hline
\end{tabular}




\begin{tabular}{lll}
\hline others & Dialogue & \\
$\begin{array}{l}\text { Answering questions related } \\
\text { to self-introduction dialogue }\end{array}$ & $\begin{array}{l}\text { The questions } \\
\text { through quiz }\end{array}$ & Edmodo \\
$\begin{array}{l}\text { Answering related questions } \\
\text { introducing others }\end{array}$ & & \\
$\begin{array}{l}\text { Able to introduce yourself } \\
\text { with A2 level level language }\end{array}$ & $\begin{array}{l}\text { Role Play - } \\
\text { Pasangan }\end{array}$ & \\
& Role Play - & \\
$\begin{array}{l}\text { Able to introduce others to } \\
\text { A2 level languages }\end{array}$ & $\begin{array}{l}\text { Video- Edmodo } \\
\text { Group }\end{array}$ & \\
$\begin{array}{l}\text { Retelling the identity of } \\
\text { others verbally with A2 level } \\
\text { language }\end{array}$ & $\begin{array}{l}\text { Self } \\
\text { Reflection }-\end{array}$ & Live Journal \\
$\begin{array}{l}\text { Rewrite the other people's } \\
\text { identities in text form with } \\
\text { A2 level language }\end{array}$ & & \\
$\begin{array}{l}\text { Rewrite the other people's } \\
\text { identities in biographical } \\
\text { form with A2 level language }\end{array}$ & Report & Edmodo Report \\
\hline
\end{tabular}

The explanation in both tables above is the content of the material in chapter one of the instructional material developed. Thus the preparation for chapter two and so on, so that it appears Basic Competencies, Indicators of Achievement of Competence and Technology, and connected to Pegagogics.

\section{Conclusion}

This paper was as the result of the initial data collection which still contained the content features of the teaching materials to be developed. In one chapter there was one Basic Competency, nine Indicators of Achievement of Competence, seven types of pedagogical that would be loaded and the number of technologies to be used. The tables displayed are features of the TPACK content that would be developed in developing TpaCK based teaching materials. 


\section{References}

[1] Plomp, Tjeerd.: Educational \& Training Systems Design. Introduction. Enschede: University of Twente, Faculty of Educational Science and Technologie Enschede(1997)

[2] Tomlinson. 1998. Materials Development in Language Teaching, United Kingdom: Cambridge University Press.(1998) 